\title{
PENGARUH LEVERAGE, STRUKTUR MODAL, DAN \\ PROFITABILITAS TERHADAP PRICE EARNING RATIO (PER), PADA \\ PERUSAHAAN PROPERTY DAN REAL ESTATE YANG TERDAFTAR \\ DI BURSA EFEK INDONESIA (BEI) TAHUN 2009-2015.
}

\author{
ABSTRAK \\ Citrasari \\ Citraisari09@gmail.com
}

Penelitian ini bertujuan untuk menganalisis Leverage, struktur Modal, Profitabilitas, Price Earning Ratio (PER) pada perusahaan Property dan Real Estate yang terdapat di BEI tahun 2009-2015.

Metode penelitian yang digunakan dalam penelitian ini adalah metode deskriptif verifikatif, karena adanya variabel-variabel yang akan ditelaah hubungannya serta tujuannya untuk menyajikan gambaran secara terstruktur, factual, dan akurat mengenai fakta-fakta serta hubungan antar variabel yang diteliti, yaitu Pengaruh Leverage, Struktur Modal dan Profitabilitas terhadap Price Earning Ratio.

Penelitian ini dilakukan pada perusahaan Property dan Real Estate yang terdaftar di Bursa Efek Indonesia dengan jumlah sampel 17 perusahaan.

Dari hasil analisis data penelitian, diperoleh simpulan sebagai berikut :

1. Nilai rata-rata leverage paling tinggi adalah PT. Megapolitan Tbk, nilai ratarata struktur modal paling tinggi PT. Agung Podomoro Land, Tbk, dan Nilai rata-rata Profitabilitas paling tinggi adalah PT. Lippo Cikarang, Tbk.

2. Nilai rata-rata PER paling tinggi adalah PT. Kawasan Industri jababeka Tbk.

3. Secara simultan Leverage, Struktur Modal dan Profitabilitas terdapat pengaruh positif dan signifikan terhadap Price Earning Ratio.

4. Secara Parsial Leverage, Struktur Modal dan Profitabilitas berpengaruh positif dan tidak signifikan terhadap Price Earning Ratio.

Berdasarkan hal tersebut, maka diperlukan penelitian lebih lanjut tentang faktor-faktor yang mempengaruhi price earning ratio selain faktor-faktor yang diteliti pada tesis ini. Diharapkan dengan menambah faktor lain, informasi yang mempengaruhi price earning ratio akan lebih lengkap dan menyeluruh.

Keywords : Leverage, Struktur Modal, Profitabilitas, Price Earning Ratio (PER). 


\begin{abstract}
Citrasari, 15132020082, Leverage Influence, Capital Structure, and Profitability to Price Earning Ratio (PER), on Property and Real Estate Company listed in Indonesia Stock Exchange (IDX) Year 2009-2015.
\end{abstract}

This study aims to analyze the Leverage, Capital Structure, Profitability, Price Earning Ratio (PER) in Property and Real Estate companies listed on BEI 2009-2015.

The research method used in this research is descriptive method verifikatif, because of the variables that will be examined its relationship and its purpose to present the picture in a structured, factual, and accurate about the facts and the relationship between variables studied, the influence of leverage, capital structure and Profitability to Price Earning Ratio.

This research was conducted at Property and Real Estate company listed in Bursa Efek Indonesia with sample number 17 companies. From the results of the analysis of research data, obtained the following conclusions:

1. The highest average leverage is PT. Megapolitan Tbk, the average value of the highest capital structure of PT. Agung Podomoro Land, Tbk, and the highest average value of Profitability is PT. Lippo Cikarang, Tbk. 2. The highest average value of PER is PT. Kawasan Industri jababeka Tbk. 3. Simultaneously Leverage, Capital Structure and Profitability there is a positive and significant influence on Price Earning Ratio.

4. Partially Leverage, Capital Structure and Profitability have positive and not significant to Price Earning Ratio.

Based on this, further research is needed on the factors that influence the price earning ratio in addition to the factors studied in this thesis. Expected by adding other factors, information affecting price earning ratio will be more complete and comprehensive.

Keywords: Leverage, Capital Structure, Profitability, Price Earning Ratio (PER). 


\section{PENDAHULUAN}

Peningkatan laba oleh perusahaan dapat ditempuh dengan berbagai cara, salah satunya dengan berinvestasi pada pasar modal. Sektor properti dan real estate sebagai salah satu instrumen usaha yang biasanya dipilih investor. Properti dan Real Estate merupakan salah satu alternatif investasi yang diminati investor dimana investasi di sektor ini merupakan investasi jangka panjang dan properti merupakan aktiva multiguna yang dapat digunakan oleh perusahaan sebagai jaminan, oleh karena itu perusahaan properti dan real estate mempunyai struktur modal yang tinggi. Harga tanah yang cenderung naik dari tahun ke tahun yang dikarenakan jumlah tanah yang terbatas sedangkan permintaan akan semakin tinggi karena semakin bertambahnya jumlah penduduk dan penentu harga bukanlah pasar tetapi orang (pihak) yang menguasai tanah tersebut membuat industri properti dan real estate ini semakin banyak disukai oleh investor ataupun kreditor.

Pemerintah Indonesia juga sangat mendukung penyediaan rumah bagi masyarakatnya melalui PP No. 41 Tahun 1996, serta hal ini didukung kalangan perbankan yang sejauh ini memiliki rasio keuangan yang sangat bagus. (sumber: www.metrotvnews.com 28 september 2010).

Faktor-faktor ekonomi yang mempengaruhi perusahaan untuk memprediksi perkembangan perusahaan di masa yang akan datang. Faktor yang membentuk harga saham merupakan factor yang ikut membentuk Price Earning Ratio (PER).

PER sebagai indikator kepercayaan pasar modal terhadap pertumbuhan perusahaan. Banyak investor di pasar modal yang menaruh perhatian pendekatan terhadap PER. Pergerakan harga saham dapat mengakibatkan perubahan PER dari saham perusahaan. Kondisi perusahaan yang diukur dengan menggunakan rasio-rasio keuangan yang terdiri dari rasio likuiditas, rasio aktivitas, rasio prfitabilitas, dan rasio leverage fluktuatif nilai penjualan dapat berpengaruh pada laba usaha yang berpengaruh pada laba bersih. Yang pada akhirnya dapat menimbulkan reaksi pasar saham, sehingga dapat berpengaruh terhadap nilai perusahaan di pasar yang tercermin pada nilai PER- 
nya. Selain itu, nilai perusahaan juga dipengaruhi oleh aspek profitabilitas dan aspek struktur permodalan perusahaan.

Profitabilitas adalah kemampuan perusahaan memperoleh laba dalam hubungannya dengan penjualan, total aktiva, maupun modal sendiri. Jadi dapat di simpulkan bahwa profitabilitas merupakan penilaian kinerja perusahaan yang diukur dengan beberapa model, seperti ROI, ROA, EPS dan ROE. ROE merupakan kemampuan perusahaan dalam menghasilkan keuntungan bagi investor. Analisis ROE berkaitan erat dengan komposisi sumber pendanaan perusahaan. ROE merupakan perbandingan antara laba bersih dengan modal sendiri. Perusahaan yang mampu menghasilkan keuntungan di atas biaya modal, dengan asumsi kondisi normal akan memperoleh tingkat ROE lebih rendah bila hanya mengandalkan modal sendiri. Sebaliknya bila manajer mengurangi sumber modal sendiri dan menggantikan kekurangan dana tersebut melalui hutang, ROE perusahaan cenderung lebih tinggi. Dari ilustrasi ini tampak bahwa tingkat ROE sangat peka terhadap kebijakan manajer dalam menentukan tingkat hutang dalam mendanai aktiva perusahan. Kebijakan manajer memanfaatkan hutang untuk mendanai aktiva perusahaan disebut leverage.

Perusahaan dalam memanfaatkan leverage melihat dari dua hal yaitu Rasio Leverage dan Financial Leverage. Hal pertama Rasio leverage yang terdiri dari Debt to Asset Rasio,Debt to Equity Rasio,dan Long Term Debt to Equity Rasio. Tetapi penelitian ini hanya menggunakan Debt to Equity Rasio (DER), DER merupakan rasio yang menunjukkan tingkat aktiva yang dibiayai oleh hutang perusahaan. Lalu hal kedua Financial Leverage di ukur dengan Degree Financial Leverage (DFL) yang dapat memberikan gambaran bahwa peningkatan leverage akan meningkatkan tingkat pengembalian yang diberikan kepada pemegang saham. Pada prinsipnya leverage keuangan mengacu pada pengertian penggunaan asset dan sumber dana (source of fund) oleh perusahaan yang memiliki beban tetap dengan maksud agar meningkatkan keuangan pontensial bagi pemegang saham. Pada kondisi yang bagus atau stabil, penggunaan financial leverage dapat memberikan pengaruh positif berupa peningkatan ROE. Hal ini dikarenakan tingkat pengembalian terhadap laba 
operasi perusahaan lebih besar dari pada beban tetapnya. Sedangkan penggunaan financial leverage dapat memberikan negative berupa penurunan ROE, bila hal tersebut digunakan pada kondisi ekonomi kurang stabil. Pengaruh negatif ini disebabkan tingkat pengembalian investasi terhadap laba perusahaan kecil dan ditambah beban bunga yang harus dibayar, maka penggunaan financial leverage dapat menimbulkan resiko keuangan perusahaan.

Berdasarkan uraian di atas penulis tertarik untuk meneliti lebih dalam tentang Leverage, Struktur Modal, Profitabilitas dan Price Earning Ratio (PER) pada perusahaan property dan real estate dengan mengajukan judul penelitian tesis : "Pengaruh Leverage, Struktur Modal Dan Profitabilitas Terhadap Price Earning Ratio (PER) Pada Perusahaan Property Dan Real Estate Yang Terdaftar Di Bursa Efek Indonesia (BEI) Tahun 2009-2015”.

\section{IDENTIFIKASI MASALAH}

Berdasarkan pada data, pendapat dan hasil penelitian dilatar belakang penelitian maka identifikasi masalah penelitian tesis ini adalah sebagai berikut:

1. Pergerakkan rata-rata Price Earning Ratio (PER) perusahaan property dan real estate yang terdaftar di BEI dari tahun 2009-2015 cenderung berfluktuasi.

2. Leverage perusahaan property dan real estate yang terdaftar di BEI dari tahun 2009-2015 cenderung berfluktuasi.

3. Struktur Modal yang ditunjukkan penjualan perusahaan property dan real estate yang terdaftar di BEI pada tahun 2014 cenderung naik di tahun 2015.

4. Profitabilitas perusahaan property dan real estate yang terdaftar di BEI sangat bervariasi.

5. Profitabilitas perusahaan property dan real estate yang terdaftar di BEI tahun 2009-2015 ada yang dibawah rata-rata.

\section{RUMUSAN MASALAH}

Adapun permasalahan yang akan dikemukakan penulis sebagai berikut : 
1. Bagaimana Leverage, struktur Modal, Profitabilitas, Price Earning Ratio (PER) pada perusahaan Property dan Real Estate yang terdapat di BEI tahun 2009-2015.

2. Seberapa besar pengaruh Leverage, struktur Modal, Profitabilitas, secara simultan terhadap Price Earning Ratio (PER) pada perusahaan Property dan Real Estate yang terdapat di BEI tahun 2009-2015.

3. Seberapa besar pengaruh Leverage, struktur Modal, Profitabilitas, secara parsial terhadap Price Earning Ratio (PER) pada perusahaan Property dan Real Estate yang terdapat di BEI tahun 2009-2015.

\section{TUJUAN PENELITIAN}

Tujuan Penelitian ini adalah sebagai berikut :

1. Untuk menganalisis Leverage, struktur Modal, Profitabilitas, Price Earning Ratio (PER) pada perusahaan Property dan Real Estate yang terdapat di BEI tahun 2009-2015.

2. Untuk menganalisis pengaruh Leverage, struktur Modal, Profitabilitas, secara simultan terhadap Price Earning Ratio (PER), pada perusahaan Property dan Real Estate yang terdapat di BEI tahun 2009-2015.

3. Untuk menganalisis pengaruh Leverage, struktur Modal, Profitabilitas, secara parsial terhadap Price Earning Ratio (PER) pada perusahaan Property dan Real Estate yang terdapat di BEI tahun 2009-2015.

\section{TINJAUAN PUSTAKA}

\section{ANALISIS LAPORAN KEUANGAN}

analisis laporan keuangan menurut Sofyan Syafri Harahap (2009:190) adalah sebagai berikut :

"Menguraikan pos-pos laporan keuangan menjadi unit informasi yang lebih kecil dan melihat hubungannya yang bersifat signifikan atau yangmempunyai makna antara satu dengan yang lain baik antara datakuantitatif maupun data nonkuantitatif dengan tujuan untuk mengetahuikondisi keuangan lebih dalam yang sangat penting dalam prosesmenghasilkan keputusan yang tepat." 
analisis laporan keuangan menurut Wild, Subramanyam, Halsey (2005: 202) adalah sebagai berikut :

“Analisis laporan keuangan adalah seni untuk mengubah data dari laporan keuangan ke informasi yang berguna bagi pengambil keputusan. Analisis keuangan (financial analysis) melibatkan penggunaan berbagai laporan keuangan. Laporan ini melaksanakan beberapa fungsi. Pertama, Neraca(Balance Sheet) meringkas aktiva, kewajiban, dan ekuitas pemilik suatu perusahaan pada suatu periode waktu tertentu. Walaupun neraca menyajikan gambaran singkat posisi keuangan perusahaan pada suatu periode waktu, laporan rugi laba menyajikan ringkasan profitabilitas perusahaan pada tahun berjalan. Dari kedua laporan keuangan ini (ditambah dalam beberapa kondisi, sedikit informasi tambahan), laporan turunan tertentu dapat dihasilkan,seperti laporan laba ditahan, laporan sumber dan penggunaan dana,serta laporan arus kas.”

analisis laporan keuangan menurut Slamet Munawir (2007:64) adalah sebagai berikut : "Laporan keuangan merupakan alat yang sangat penting untukmemperoleh informasi yang berhubungan dengan posisi keuangan danhasilhasil yang telah dicapai oleh perusahaan yang bersangkutan.Mengadakan analisa hubungan dari berbagai pos dalam suatu laporankeuangan adalah merupakan dasar untuk dapat menginterpretasikan kondisi keuangan dan hasil operasi suatu perusahaan."

\section{LEVERAGE}

Syamsuddin (2002:90) mengemukakan bahwa Rasio Leverage merupakan kemampuan perusahaan untuk menggunakan aktiva atau dana yang mempunyai beban tetap (fixed cost assets or funds) yang gunanya untuk memperbesar tingkat penghasilan (return) bagi pemilik perusahaan.

\section{STRUKTUR MODAL}

Riyanto, (2001) mengemukakan struktur modal adalah perimbangan atau perbandingan antara modal asing (jangka panjang) dengan modal sendiri. Teori struktur modal menjelaskan adanya pengaruh perubahan stuktur modal terhadap 
nilai perusahaan, apabila keputusan investasi dan kebijakan dividen yang dipegang konstan. Sumber dana internal perusahaan berasal dari laba ditahan dan depresiasi. Dana yang diperoleh dari sumber eksternal adalah dana dari para kreditur dan pemilik, peserta atau pengambilan bagian dalam perusahaan.

Menurut Brigham dan Houston (2001) struktur modal adalah bauran dari hutang, saham preferen dan saham biasa. Sedangkan menurut Weston \& Copeland (2002) struktur modal adalah pembiayaan permanen yang terdiri dari hutang jangka panjang, saham preferen, dan modal pemegang saham. Abas Kartadinata (1999) mengemukakan struktur keuangan menggambarkan susunan keseluruhan sebelah kredit neraca yang terdiri atas hutang-hutang jangka pendek, hutang-hutang jangka panjang, modal saham, dan laba yang ditanam kembali. Sedangkan struktur modal adalah susunan atau perbandingan antara modal sendiri dan pinjaman jangka panjang, jadi struktur modal merupakan bagian dari struktur keuangan.

\section{PROFITABILITAS}

Profitabilitas adalah kemampuan perusahaan untuk memperoleh laba dalam periode tertentu (Riyanto, 2001).

Profitabilitas merupakan variabel independen penting yang mempunyai pengaruh pada struktur modal. Semakin tinggi profit suatu perusahaan maka akan semakin menurun hutangnya karena semakin banyak dana internal yang tersedia untuk mendanai investasinya (Brigham dan Houston,2001).

Menurut Raharjaputra (2009:195), Profitabilitas adalah kemampuan perusahaan dalam memperoleh laba atau keuntungan, dimana hubungannya dengan penjualan, total aktiva, maupun modal sendiri.

Wiagustini (2010:76) mengatakan profitabilitas adalah menunjukkan kemampuan perusahaan memperoleh laba atau ukuran efektivitas pengelolaan manajemen perusahaan.

\section{Price Earning Ratio (PER)}

Salah satu cara untuk menghitung sekuritas yang baik bagi investor dengan cara menggunakan price earning ratio. Menurut Van Horne dan Wachowicz (2005), price earning ratio (PER) adalah ukuran kineja saham yang didasarkan atas 
perbandingan antara harga pasar saham terhadap pendapatan perlembar saham (Earning Per Share, EPS).

Pertumbuhan laba dan dividen serta expected rate of return dari suatu saham berubah-ubah nilainya, maka PER diharapkan juga akan berubah sepanjang waktu berjalan dan pada akhirnya menuju suatu tingkat nilai PER rata-rata dari sahamsaham yang mempunyai tingkat risiko yang sama. Expected rate of return menurut Ang (1997) dapat dilihat dari dua sisi yaitu dari pihak investor, tinggi rendahnya tingkat laba yang disyaratkan merupakan pencerminan oleh tingkat risiko aktiva dan struktur modal.

\section{Kerangka Pemikiran}

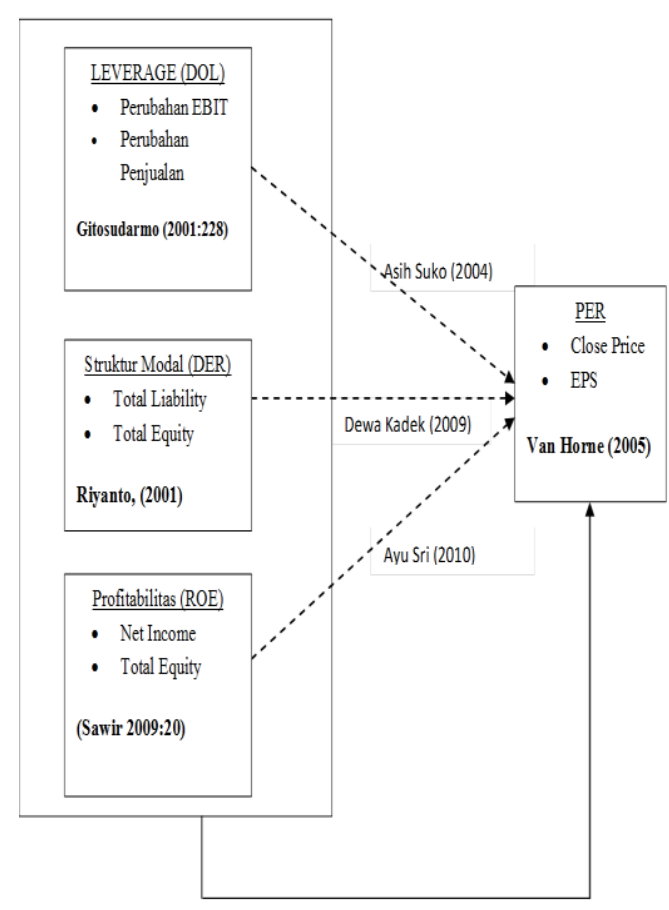

Gambar 2.1

Kerangka Pemikiran

Keterangan

:Pengaruh Secara Simultan

: Pengaruh Secara Parsial 


\section{Hipotesa Penelitian}

1. Terdapat pengaruh Leverage, Struktur Modal, dan Profitabilitas secara simultan terhadap Price Earning Ratio (PER) pada Perusahaan Property dan Real Estate yang terdapat di Bursa Efek Indonesia tahun 2009-2015.

2. Terdapat pengaruh Leverage, Struktur Modal, dan Profitabilitas secara parsial terhadap Price Earning Ratio (PER) pada Perusahaan Property dan Real Estate yang terdapat di Bursa Efek Indonesia tahun 2009-2015.

\section{METODOLOGI PENELITIAN}

Metode yang akan digunakan dalam penelitian ini adalah metode deskriptif dan verifikatif, karena adanya variabel-variabel yang akan ditelaah keterkaitannya. Metode deskriptif adalah suatu metode dalam meneliti status kelompok manusia, suatu obyek, suatu kondisi, suatu sistem pemikiran ataupun suatu kelas peristiwa pada masa sekarang. Menurut Husein Umar (2009 : 22) metode ini bertujuan untuk menggambarkan sifat sesuatu yang tengah berlangsung pada saat penelitian dilakukan dan memeriksa sebab-sebab dari suatu gejala tertentu. Metode verifikatif digunakan untuk mengetahui hubungan antara variabel melalui pengujian hipotesis.

\section{Operasionalisasi Variabel}

Definisi operasional variabel adalah unsur penelitian yang memberitahukan bagaimana cara mengukur suatu variabel. Dalam penelitian ini variabel yang diteliti dibagi menjadi dua kelompok besar, yaitu variabel bebas (independent variable) dan variabel terikat (dependen variable). Variabel bebas adalah variabel yang nilainya tidak tergantung dari variabel yang lain dan variabel terikat adalah variabel yang nilainya tergantung dari variabel lain.

\section{Instrumen Penelitian}

1. Variabel $X$ (variabel independen adalah variabel yang mempengaruhi atau yang menjadi sebab perubahannya atau timbulnya variabel dependen. Yang termasuk variabel independen adalah sebagai berikut :

1). Leverage : Degree Of Leverage $(D O L)\left(\mathrm{X}_{1}\right)$ 


\section{2). Struktur Modal : Debt Equity Ratio $(D E R)\left(\mathrm{X}_{2}\right)$}

3). Profitabilitas : Return On Equity $(R O E)\left(\mathrm{X}_{3}\right)$

2. Variabel Y (variabel dependen)

Variabel dependen merupakan variabel yang dipengaruhi atau yang menjadi akibat, karena adanya vairabel bebas. Price Earning Ratio (PER) sebagai variabel dependen $(\mathrm{Y})$.

\section{Sumber Data}

Data yang digunakan dalam penelitian ini dikumpulkan dengan menggunakan metode historis dan secara online, berupa laporan keuangan yang berasal dari website resmi yang dimiliki oleh Bursa Efek Indonesia, yaitu www.idx.co.id. Data laporan keuangan yang diperlukan mencakup data tahun 2009 sampai dengan 2015. Penelitian ini menggunakan data sekunder yang berupa data rasio-rasio laporan keuangan perusahaan property dan real estate yang diperoleh dari website resmi bursa efek indonesia, yaitu www.idx.co.id tahun 2009 sampai dengan 2015. Datadata yang diperoleh meliputi DER, DOL, ROE, dan PER. Data laporan keuangan berupa data time series 6 tahun, periode waktu tersebut merupakan rentang waktu yang tepat untuk mendapatkan jumlah data yang diinginkan.

\section{Uji Hipotesis}

Penelitian ini merupakan penelitian yang bertujuan untuk mengetahui pengaruh variabel independen $(\mathrm{X})$ terhadap variabel dependen $(\mathrm{Y})$. Oleh karena itu untuk mengetahui hubungan antara variabel digunakan persamaan regresi sederhana dan berganda. Pengujian terhadap hipotesis yang dilakukan dalam penelitian ini dilakukan dengan cara sebagai berikut :

\section{Uji Hipotesis Secara Simultan (Uji F-Statistik)}

Uji F-statistik pada dasarnya menunjukkan apakah semua variabel bebas yang dimasukkan dalam model regresi mempunyai pengaruh secara simultan terhadap variabel terikat (Ghozali, 2002:44). Arti dari simultan adalaah jika salah satu variabel bebas dalam penelitian signifikan terhadap variabel bebas. Tingkat signifikasi yang digunakan dalam penelitian ini $\alpha=5 \%$. Derajat kebebasan (degree 
of freedom $) \mathrm{df}=(\mathrm{n}-\mathrm{k})$ dimana $\mathrm{n}$ adalah jumlah observasi, $\mathrm{k}$ adalah jumlah variabel bebas. $F_{\text {tabel }}$ akan dicari berdasarkan tingkat signifikasi. Jika $F_{\text {hitung }}>F_{\text {tabel }}$ hal ini berarti variabel bebas mampu menjelaskan variabel terikat secara simultan / bersama. Sebaliknya jika $F_{\text {hitung }}<\mathrm{F}_{\text {tabel, }}$ hal ini berarti bahwa variabel bebas secara bersama-sama tidak mampu memnjelaskan variabel terikatnya.

a) Ho ditolak apabila nilai $F_{\text {hitung }}>F_{\text {tabel}}$, berarti ada pengaruh

b) Ho diterima apabila nilai $\mathrm{F}_{\text {hitung }}<\mathrm{F}_{\text {tabel, }}$, berarti tidak ada pengaruh

Rumus uji F-statistik menurut Sugiyono (2010:257)

$$
\begin{aligned}
& F=\frac{R^{2} / k}{\left(1-R^{2)} /(n\right.} \\
& \text { Keterangan }: \\
& R^{2}=\text { Koefisien determinasi } \\
& k=\text { jumlah variabel independen } \\
& n=\text { Jumlah data }
\end{aligned}
$$

\section{Uji Hipotesis Secara Parsial (Uji T- statistik)}

Uji T- statistik pada dasarnya menunjukkan seberapa jauh pengaruh satu variabel bebas secara individual dalam menerangkan variasi variabel independen (Ghozali, 2002 : 44). Sedangkan, menurut Situmorang dan Lutfi (2011:157) menyatakan untuk menguji apakah hipotesis yang diajukan diterima atau ditolak digunakan statistik $\mathrm{t}$ (uji $\mathrm{t}$ ). apabila $\mathrm{t}_{\text {hitung }}>\mathrm{t}_{\text {tabel }}$ atau (- $\mathrm{t}_{\text {hitung }}>\left(-\mathrm{t}_{\text {tabel }}\right)$ pada signifikan $\alpha=5 \%$, dikatakan variabel bebas memiliki pengaruh secara signifikan terhadap variabel terikat sebaliknya $t_{\text {hitung }} \leq \mathrm{t}_{\text {tabel }}$ atau $\left(-\mathrm{t}_{\text {hitung }}\right) \geq\left(-\mathrm{t}_{\text {tabel }}\right)$ berarti bahwa variabel bebas tidak berpengaruh secara signifikan terhadap variabel terikat secara individual.

a) Ho ditolak apabila nilai $t_{\text {hitung }}>t_{\text {tabel }}$, berarti ada pengaruh

b) Ho ditolak apabila nilai $t_{\text {hitung }}<t_{\text {tabel }}$, berarti tidak ada pengaruh

Rumus uji t-statistik menurut sugiyono, (2010:230) :

$$
t=\frac{\mathrm{r} \sqrt{\mathrm{n}-2}}{\sqrt{1-r^{2}}}
$$


Keterangan :

$\mathrm{t}=$ uji t-statistik

$\mathrm{n}=$ jumlah data

$\mathrm{r}=$ koefisien korelasi parsial

\section{HASIL DAN PEMBAHASAN}

\section{Analisis Regresi Berganda}

Rumus Persamaan Regresi Berganda :

$$
\mathrm{Y}=\mathrm{a}+\beta_{1} \mathrm{X}_{1}+\beta_{2} \mathrm{X}_{2}+\beta_{3} \mathrm{X}_{3}+\mathrm{e}
$$

$\hat{Y}=3,721+(2,841) \mathrm{X}_{1}+(0,315) \mathrm{X}_{2}+(2,437) \mathrm{X}_{3}$

$\begin{array}{lllll}\text { Sign } & 0,000 & 0,279 & 0,201 & 0,111 \\ \mathrm{t} & 3.757 & 1.807 & 1.285 & 1.678\end{array}$

persamaan regresi berganda di atas, maka dapat dijelaskan bahwa :

a. Apabila tidak ada perubahan variabel $\mathrm{X}_{1}, \mathrm{X}_{2}$, dan $\mathrm{X}_{3}$ atau masing-masing nilainya 0 (konstan) maka PER bernilai 3,721;

b. Apabila terjadi kenaikan terhadap variabel $X_{1}$ sebesar satu satuan, dan kondisi-kondisi $\mathrm{X}_{2}$ dan $\mathrm{X}_{3}$ pada posisi stabil (tidak berubah), maka variabel Y akan mengalami penurunan sebesar 2,841 satuan atau sebaliknya. Kalinya dan atau sebaliknya dengan asumsi $\mathrm{X}_{2}$ dan $\mathrm{X}_{3}$ tetap.

c. Apabila terjadi kenaikan terhadap variabel $\mathrm{X}_{2}$ sebesar satu satuan, dan kondisi-kondisi $\mathrm{X}_{1}$ dan $\mathrm{X}_{3}$ pada posisi stabil (tidak berubah), maka variabel Y akan mengalami penurunan sebesar 0,135 satuan atau sebaliknya. Kalinya dan atau sebaliknya dengan asumsi $\mathrm{X}_{1}$ dan $\mathrm{X}_{3}$ tetap.

d. Apabila terjadi kenaikan terhadap variabel $\mathrm{X}_{3}$ sebesar satu satuan, dan kondisi-kondisi $\mathrm{X}_{1}$ dan $\mathrm{X}_{2}$ pada posisi stabil (tidak berubah), maka variabel Y akan mengalami penurunan sebesar 2,437 satuan atau sebaliknya. Kalinya dan atau sebaliknya dengan asumsi $X_{1}$ dan $X_{2}$ tetap.

a. Koefisien korelasi (R) sebesar 0,573 yang menunjukkan hubungan antara variabel Leverage, Struktur Modal, Profitabilitas Terhadap PER adalah 
positif 0,573. Hubungan sebesar 0,573 membuktikan bahwa hubungan antara variabel Leverage, Struktur Modal, Profitabilitas dengan PER adalah cukup.

b. Koefisien determinasi $\left(\mathrm{R}^{2}\right)$ menggunakan adjusted $\mathrm{R}$ square sebesar 0,525, hasil tersebut menunjukkan bahwa besarnya PER yang dapat dijelaskan oleh variabel Leverage, Struktur Modal, Profitabilitas adalah sebesar 52,5\% dan yang dijelaskan oleh variabel lain di luar model sebesar 47,5\% (100\%$52,5 \%)$. Dengan demikian Leverage, Struktur Modal, Profitabilitas apabila dilakukan secara bersama-sama, maka akan meningkatkan PER sebesar $52,5 \%$.

\section{Pembahasan Hasil Penelitian}

1. Leverage, Struktur Modal, Profitabilitas dan Price Earning Ratio pada perusahaan Property dan Real Estate yang tergabung di BEI tahun 2009-2015.

a. Leverage (DOL) memiliki rata-rata yang paling tinggi sebesar 3,30, sedangkan, rata-rata yang paling rendah sebesar 0,11. Selama periode tahun 2009 sampai dengan tahun 2015 rata-rata Leverage yang paling tinggi dicapai oleh PT. Megapolitan Development, Tbk yaitu dengan ratarata sebesar 5,86. Sedangkan, rata-rata leverage yang paling rendah diperoleh PT. Modernland Realty, Tbk yaitu dengan nilai rata-rata 0,001. Standar deviasi adalah 35,6 persen lebih tinggi dari rata-rata leverage periode 2009-2015, ini menunjukkan stabilnya leverage perusahaan sektor property dan real estate yang terdaftar di Bursa Efek Indonesia pada tahun 2009-2015.

Secara teori perusahaan sudah mampu menggunakan aktiva atau dana yang mempunyai beban tetap (fixed cost assets or funds) dan sudah optimal untuk memperbesar tingkat penghasilan (return) bagi pemilik perusahaan.

b. Struktur Modal (DER) memiliki rata-rata yang paling tinggi sebesar 102,62. Sedangkan, rata-rata yang paling rendah sebesar 81,49. Selama periode tahun 2009 sampai dengan tahun 2015 rata-rata yang paling tinggi Struktur Modal (DER) dicapai oleh PT. Agung Podomoro Land, Tbk yaitu dengan rata-rata sebesar 153,49. Sedangkan, rata-rata Struktur Modal 
(DER) yang paling rendah diperoleh PT. Bukit Darmo Property, Tbk yaitu dengan nilai rata-rata 30,29.

Standar deviasi adalah 28,6 persen lebih tinggi dari rata-rata struktur modal periode 2009-2015, ini menunjukkan stabilnya struktur modal perusahaan sektor property dan real estate yang terdaftar di Bursa Efek Indonesia pada tahun 2009-2015.

Secara teori perusahaan sudah dapat memenuhi kewajiban jangka pendek dan jangka panjang secara optimal.

c. Profitabilitas (ROE) memiliki rata-rata yang paling tinggi sebesar 15,43, sedangkan rata-rata yang paling rendah sebesar 6,80. Selama periode tahun 2009 sampai dengan tahun 2015 rata-rata ROE yang paling tinggi dicapai oleh PT. Lippo Cikarang, Tbk yaitu dengan rata-rata sebesar 24,88. Sedangkan, rata-rata ROE yang paling rendah diperoleh PT. Bukit Darmo Property, Tbk yaitu dengan nilai rata-rata -3,56.

Standar deviasi adalah 0,13 persen rendah dari rata-rata Profitabilitas periode 2009-2015, hal ini menunjukkan stabilnya profitabilitas perusahaan sektor property dan real estate yang terdaftar di bursa efek Indonesia pada tahun 2009-2015.

Secara teori ROE mendekati 1 menunjukkan semakin efektif dan efisien penggunaan ekuitas perusahaan untuk menghasilkan pendapatan Perusahaan. Dalam penelitian ini menunjukkan bahwa perusahaan property dan real estate rata-rata memiliki kemampuan profitabilitas yang tinggi.

d. Price Earning Ratio (PER) memiliki rata-rata yang paling tinggi sebesar 23,93, sedangkan rata-rata yang paling rendah sebesar 7,69. Selama periode tahun 2009 sampai dengan tahun 2015 rata-rata yang paling tinggi PER dicapai oleh PT. Kawasan Industri Jababeka, Tbk yaitu dengan ratarata sebesar 54,4. Sedangkan, rata-rata PER yang paling rendah diperoleh PT. Duta Anggada realty, Tbk yaitu dengan nilai rata-rata 0,02.

Standar deviasi adalah 2,48 persen lebih tinggi dari rata-rata PER periode 2009-2015, hal ini menunjukkan stabilnya PER perusahaan sektor property dan real estate yang terdaftar di bursa efek Indonesia pada tahun 20092015. 
Secara teori PER pada perusahaan property dan real estate menunjukkan bahwa saham perusahaan property dan real estate ditingkat yang bagus karena semakin tinggi PER bagi pemodal akan semakin bagus. Semakin tinggi PER maka semakin besar kepercayaan investor terhadap masa depan perusahaan.

2. Pengaruh Leverage, Struktur Modal, Profitabilitas secara simultan terhadap PER pada perusahaan Property dan Real estate yang tergabung di BEI tahun 2009-2015.

Dari hasil uji F di atas menunjukkan bahwa nilai Fhitung sebesar 6,456 dan Ftabel sebesar 2,68 (didapat dari $\mathrm{N}=119$; df1 = 4-1 = 3 dan df2 = 119-4 = 115, maka NIlai F Tabel adalah 2,68). Karena Fhitung lebih besar dari pada Ftabel, dan nilai p-value adalah 0.000 (sig) lebih kecil dari alpha 0.05 (confidence interval), maka dapat disimpulkan bahwa koefisien regresi secara keseluruhan adalah signifikan pada tingkat 5\%, Dimana Ho ditolak dan H1 diterima. Dengan demikian hal ini menunjukkan bahwa terdapat pengaruh yang signifikan secara bersama-sama antara Leverage, Struktur Modal dan Profitabilitas terhadap PER.

3. Pengaruh Leverage, Struktur Modal, Profitabilitas secara parsial terhadap PER pada perusahaan otomotif dan komponen yang tergabung di BEI tahun 20102014.

\section{a. Leverage}

Berdasarkan hasil penelitian secara parsial diperoleh bahwa Leverage berpengaruh positif terhadap PER. Leverage berpengaruh secara parsial terhadap PER karena t hitung lebih besar dari t tabel.

Variabel leverage memiliki nilai t hitung sebesar 1,807 , lebih besar dari nilai t tabel sebesar 1.6246 dengan tingkat signifikansi 0,279 lebih besar dari pada 0,05 . Dengan demikian arahnya berpengaruh dan signifikan terhadap PER.

Hasil penelitian ini mendukung penelitian yang dilakukan oleh Asih Suko (2014) yang diperoleh bahwa Leverage berpengaruh negatif dan signifikan 
terhadap PER, sedangkan Struktur Modal memiliki pengaruh Positif terhadap PER.

\section{b. Struktur Modal}

Berdasarkan hasil penelitian secara parsial diperoleh hasil uji t menunjukkan bahwa nilai t tabel sebesar 1,6246 dan nilai t hitung untuk Struktur Modal sebesar 1,285 Karena t hitung $\leq \mathrm{t}$ tabel, dan nilai $\mathrm{p}$-value adalah 0,201 (sig) lebih besar dari alpha 0.05 (confidence interval), artinya bahwa Struktur Modal memiliki pengaruh negatif dan tidak signifikan terhadap PER.

\section{c. Profitabilitas}

Berdasarkan hasil penelitian secara parsial Dari hasil uji $\mathrm{t}$ di atas menunjukkan bahwa nilai t tabel sebesar 1.6246 dan nilai t hitung untuk Profitabilitas sebesar 1,678 Karena $t$ hitung $\geq \mathrm{t}$ tabel, dan nilai $\mathrm{p}$-value adalah 0.111 (sig) lebih besar dari alpha 0.05 (confidence interval), artinya pengaruh yang terjadi antara variabel Profitabilitas terhadap PER adalah pengaruh positif signifikan.

Hasil penelitian ini mendukung penelitian yang dilakukan oleh Ayu Sri (2010) yang diperoleh bahwa Profitabilitas berpengaruh Positif dan signifikan terhadap PER.

\section{PENUTUP}

\section{Simpulan}

1. Posisi Leverage yang diwakili oleh Degree Of Leverage (DOL), pada perusahaan property dan real estate sudah optimal dalam mempergunakan aktiva atau dana yang mempunyai beban tetap (fixed cost assets or funds) dalam memperbesar tingkat penghasilan (return) bagi pemilik perusahaan.

2. Kondisi Struktur Modal yang diwakili oleh Debt to Equity ratio (DER), pada perusahaan property dan real estate menunjukkan bahwa perusahaan sudah dapat memenuhi kewajiban jangka pendek dan jangka panjang secara optimal. 
3. Posisi Profitabilitas yang diwakili oleh Return On Equity (ROE), pada perusahaan property dan real estate mendekati 1 menunjukkan semakin efektif dan efisien penggunaan ekuitas perusahaan untuk menghasilkan pendapatan Perusahaan.

4. Posisi Price Earning Ratio (PER), pada perusahaan property dan real estate menunjukkan bahwa saham perusahaan property dan real estate ditingkat yang bagus karena semakin tinggi PER bagi pemodal akan semakin bagus. Semakin tinggi PER maka semakin besar kepercayaan investor terhadap masa depan perusahaan.

\section{Pengaruh Leverage, Struktur Modal, Profitabilitas secara parsial terhadap}

PER pada perusahaan Property dan Real Estate yang tergabung di BEI tahun 2009-2015.

d. Leverage

Berdasarkan hasil penelitian secara parsial diperoleh bahwa Leverage berpengaruh posittif terhadap PER. Leverage berpengaruh secara parsial terhadap PER karena thitung lebih besar dari t tabel.

e. Struktur Modal

Berdasarkan hasil penelitian secara parsial diperoleh bahwa Struktur Modal memiliki pengaruh negatif dan tidak signifikan terhadap PER.

f. Profitabilitas

Berdasarkan hasil penelitian secara parsial diperoleh bahwa pengaruh yang terjadi antara variabel Profitabilitas terhadap PER adalah pengaruh positif signifikan.

\section{Saran}

1. Bagi Investor dan perusahaan,

a. Leverage memiliki pengaruh positif terhadap PER, dalam hal ini sebaiknya perusahaan tetap memperhatikan leverage dengan selau mengawasi penuh atas kegiatan perusahaan dalam menggunakan dana dan membelanjakan dana perusahaan yang ada. 
b. Struktur Modal memiliki pengaruh negatif terhadap PER, walaupun Struktur Modal tidak memiliki pengaruh terhadap PER sebaiknya perusahaan tetap meningkatkan Struktur Modal karena akan mempengaruhi terhadap nilai perusahaan dalam pengambilan keputusan investasi.

c. Profitabilitas memiliki pengaruh positif terhadap PER, maka sebaiknya perusahaan tetap mengontrol Profitabilitas agar tetap stabil dan meningkat akan lebih baik, karena apabila Profitabilitas menurun maka Price Earning Ratio (PER) perusahaan pun akan menurun.

2. Bagi peneliti lain, perlu dilakukan penelitian lebih lanjut tentang faktorfaktor yang mempengaruhi price earning ratio selain faktor-faktor yang diteliti pada tesis ini. Diharapkan dengan menambah faktor lain, informasi yang mempengaruhi price earning ratio akan lebih lengkap dan menyeluruh.

\section{DAFTAR PUSTAKA}

Baridwan, Zaki.2004.Intermediate Accounting,Edisi Kedelapan. Yogyakarta: BPFE.

Griffin, Ricky W.2004. Manajemen, Alih bahasa Gina Gania, Edisi ketujuh, Jakarta:Erlangga.

Harjito, Agus. 2010. Manajemen Keuangan, Edisi ketiga.Yogyakarta : Ekonisia.

James C. Van Horne dan John M. Wachowichz.2005. Prinsip-prinsip Manajemen Keuangan. Edisi kedua belas. Jakarta : Salemba Empat.

Kasmir.2014.Analisa Laporan Keuangan.Jakarta: Raja Grafindo Persada.

Ksenija Dencic-Mihaljov. 2015.Impact of Account Receivable Management

On The Profitability During The Financial Crisis. Eropa: University of Nis

Riyanto, Bambang, 2011.Dasar-dasar Pembelanjaan Perusahaan, Edisi Keempat. Yogyakarta: BPFE. 